\title{
KEMAMPUAN MENULIS SISWA MENGGUNAKANPENDEKATAN PEMBELAJARAN TERPADU MATA PELAJARANBAHASA INDONESIA PADA MIS ASSALAM MARTAPURA
}

\author{
Latifah dan Tri Tunggal \\ Dosen Politeknik Kesehatan Banjarmasin \\ Email:latifahhusien@yahoo.com
}

\begin{abstract}
Abstrak
Penggunaan pendekatan pembelajaran terpadu di dalam pembelajaran kemampuan menulis dalam pembelajaran bahasa Indonesia ternyata dapat meningkatkan kemampuan menulis siswa. Hal ini terindikasi dari adanya peningkatan perolehan kemampuan menulis (KM) yang rendah meningkat ke KM yang lebih tinggi. Pelaksanaan pembelajaran bahasa Indonesia berjalan efektif dalam menerapkan pendekatan terpadu dapat mensinergikan antara kemampuan fisik dan kemampuan psikis sehingga kemampuan menulisnya meningkat. Peningkatan kemampuan menulis siswa SD Kelas Tinggi setelah diterapkan pendekatan terpadu dalam pembelajaran bahasa Indonesia adalah pada kondisi awal perolehan nilai KM adalah 57,5\%. Pada siklus perolehan KMtertinggi adalah $65 \%$.
\end{abstract}

Kata Kunci: Kemampuan Menulis Menggunakan Pendekatan Pembelajaran Terpadu

\section{PENDAHULUAN}

Dalam kehidupan modern saat ini,penguasaan bahasa tulis bagi seseorang mutlak diperlukan. Namun, dalam kenyataan pembelajaran menulis di sekolah kurang begitu mendapatkan perhatian yang memadai. Akibatnya, keterampilan menulis siswa kurang memadai. Ada beberapa penyebab kekurangberhasilan pembelajaran menulis di Sekolah Dasar. Salah satu penyebabnya ialah penyampaian materi yang masih menggunakan pendekatan tidak terpadu. Keempat keterampilan berbahasa (keterampilan menulis, membaca, menyimak, dan berbicara) ini berdiri sendiri-sendiri, bahkan dianggap sebagai ilmu tersendiri. Realisasi pembelajaran menulis secara terpadu terikat dua hal, yaitu (1) keseluruhan proses pembelajaran berorientasi pada kebermaknaan dan (2) pembelajaran berorientasi pada pembelajar. Pembelajaran dijadikan fokus utama sebagai pelaku pembelajaran. Pemikiran mengenai peningkatan kemampuan menulis siswa dengan pendekatan pembelajaran terpadu dalam pembelajaran bahasa Indonesia perlu dilakukan penelitian. Dengan demikian, peneliti akan mencoba untuk menerapkan pendekatan pembelajaran terpadu untuk pembelajaran menulis dalam bidang bahasa Indonesia pada siswa di SD kelas tinggi.

\section{LANDASAN TEORI}

\section{Kemampuan Menulis}

Menulis pada hakikatnya adalah melukiskan lambang-lambang grafis yang menggambarkan suatu bahasa yang dipahami seseorang untuk dibaca orang lain 
yang dapat memahami bahasa dan lambang-lambang grafis itu (HG Tarigan,1983:21). Sebagai bentuk penuangan gagasan, jenis-jenis tulisan berdasarkan tujuan yang disampaikan ada bermacam-macam. Keraf (1995:6-7) membagi jenis tulisan menjadi lima yaitu (1) eksposisi, (2) argumentasi, (3) persuasi, (4) deskripsi, dan (5) narasi. Selanjutnya dikemukakan bahwa persuasi merupakan varian dari argumentasi. Gorys Keraf (1984: 8-9) mengemukakan bahwa manfaat menulis, yaitu untuk(1) mengenal diri sendiri, (2) lebih memahami orang lain, (3) belajar mengamati dunia sekitar dengan cermat, dan (4) untuk mengembangkan proses berpikir secara jelas dan teratur. Dalam proses menulis sekurang-kurangnya mencakup lima unsur, yaitu (1) isi karangan, (2) bentuk karangan, (3) tata bahasa, (4) gaya, dan (5) ejaan dan tanda baca (Harris, 1974:68).

Dari beberapa pendapat tersebut, dapat disimpulkan bahwa proses menulis akademik, tahap-tahap menulis meliputi (1) tahap prapenulisan, (2) tahap penulisan, dan (3) tahap perbaikan (revisi). Tulisan yang baik mempunyai ciri-ciri (1) mudah, (2) berterima, (3) ekonomis, (4) tepat, (5) langsung,(6) utuh, dan (7) gramatikal.

\section{Penguasaan Struktur Bahasadalam Menulis}

Aspek penguasaan struktur bahasa (gramatikal) merupakan salah satu dari bekal kemampuan menulis. Penguasaan terhadap struktur bahasa berarti kemampuan untuk mengetahui struktur bahasa sesuai dengan kaidah yang berlaku. Dalam perkembangan sekarang, struktur bahasa bahkan bukan hanya tata bunyi, tata bentuk, tata kalimat, dan tata makna, melainkan sudah sampai kepada tatawacana.

\section{Penilaian Tulisan}

Dalam menilai suatu tulisan, ada beberapa cara yang digunakan. Madsen(1983:120) membagi cara penilaian karangan menjadi dua, yaitu (1) cara analitik dan (2) cara holistik. Penilaian secara analitik dalam penelitian ini dilakukan dengan melihat aspek-aspek yang ada dalam karangan. Penilaian holistik dilakukan dengan cara melihat karangan secara menyeluruh dan dalam hal ini yang dipentingkan sifat komunikasinya.

\section{Pendekatan Pembelajaran Terpadu}

\section{a. Hakikat Pembelajaran Terpadu}

Istilah terpadu oleh Nasution (1978: 10) dikaitkan dengan kurikulum terpadu bahwa pembelajaran terpadu ialah pembelajaran yang meniadakan batasbatas berbagai mata pelajaran dalam bentuk unit-unit atau keseluruhan. Kebulatan bahan pelajaran diharapkan dapat membentuk pribadi pembelajar yang terpadu, yaitu manusia yang sesuai dan selaras.

\section{b. Pendekatan Terpadu dalamPembelajaran Bahasa}

Pendekatan pembelajaran yang diterapkan dalam pembelajaran berbahasa mempunyai tujuan agar siswa tuntas berbahasa. Semua pendekatan yang dikonsepkan oleh para pakar bahasa bertujuan agar anak didik segera terampil berbahasa dalam penggunaan bahan ajar tertentu (Pateda, 1991: 98). Istilah pendekatan terpadu dikemukakan oleh Oxford, et al. (1994: 257) bahwa 
pendekatan terpadu adalah pengajaran keterampilan berbahasa pada membaca, menulis, menyimak, dan berbicara yang satu berhubungan dengan yang lain, pada waktu suatu pengajaran berisi aktivitas-aktivitas yang menghubungkan antara menyimak dan berbicara serta menulis dan membaca dengan penekanan pada kenyataan dan kebermaknaan komunikasi.

\section{c. Model Pembelajaran Terpadu}

Ditinjau dari cara memadukan konsep, keterampilan, dan unit tematiknya terdapat beberapa cara merencanakan pembelajaran terpadu. Ngalimun (2013: 17) mengajukan beberapa model pembelajaran terpadu, antara lain (1) connected, (2) nested, (3) webbed, dan (4) integrated. Dalam pembelajaran menulis diupayakan pada keterampilan berbahasa yang ditunjukkan untuk memahami isi, menggabungkan daya pikir, dan menggabungkan keterampilan sosial.

\section{d. Model Pembelajaran Terpadu dalamKeterampilan Berbahasa}

Teori keterpaduan bahasa, menurut Ngalimun (2014: 132) didasari oleh tiga prinsip, yaitu (1) pembelajar yang aktif dan konstruktif, (2) bahasa yang digunakan untuk mengungkapkan dan mengekspresikan tujuan kehidupan sosialnya dalam bermacam-macam bahasa, dan (3) pengetahuan yang diorganisasi dan disusun berdasarkan individu pembelajar melalui interaksi sosial. Di dalam pembelajaran ini porsi menulis lebih banyak dibandingkan dengan aspek keterampilan yang lain. Pola-pola pembelajaran kemampuan menulis dapat bervariasi, antara lain sebagai berikut.

Menyimak - berdiskusi - menulis

Berdiskusi - menulis - membaca

Menulis - melaporkan - membaca

Membaca - menulis - berdiskusi.

\section{METODE PENELITIAN}

Penelitian ini menggunakan metode "Classroom Action Research" yang disingkat CAR atau penelitian tindakan kelas (PTK). Siklus action research dalam penelitian tindakan kelas ini dapat digambarkan (divisualisasikan) sebagai berikut.

\section{Siklus Penelitian}

Pelaksanaan penelitian tindakan kelasini meliputi beberapa siklus. Banyaknya siklus yang digunakan tergantung hasil refleksi dari siklus sebelumnya yang berdaur ulang dan berkelanjutan dari siklus pertamake siklus berikutnya. Setiap siklus meliputi kegiatan perencanaan tindakan (planning), implementasi tindakan (acting), observasi (observing), dan refleksi (reflecting). Siap siklus dilakukan dengan memberikan tindakan pelatihan dengan berbagai penguasaan bahasa yang dikaitkan dengan karangan dan diakhiri dengan praktik menulis atau kegiatan mengarang.

\section{Prosedur Penelitian}

Prosedur penelitian mencakup: (1) perencanaan tindakan yang akan digunakan, (2) pelaksanaan tindakan, (3) observasi, dan (4) refleksi hasil tindakan 
yang telah dilakukan.Sumber data yang digunakan dalam penelitian ini adalah (a) peristiwa atau kegiatan, yaitu proses kegiatan pembelajaran menulis dengan menggunakan pendekatan pembelajaran terpadu, (b) pelaku peristiwa, yaitu informan atau narasumber dari guru bahasa dan sastra Indonesia, dan (c) dokumen berupa kurikulum dan perangkat pembelajaran guru. Teknik pengumpulan data dalam penelitian tindakan kelas ini dilakukan dengan (1) pengamatan, (2) wawancara, dan(3) tes.

\section{Analisis Data dan Refleksi}

Teknik analisis data yang digunakan didalam penelitian ini adalah teknik analisis kritis dengan dengan mendeskripsikan temuan data dan membandingkannya dengan indikator-indikator kinerja yang sudah ditentukan. Adapun indikator kinerja yang ditentukan apabila ada peningkatan jumlah siswa menguasai gramatika dalam penyusunan karangan (pada kondisi awal) dan apabila ada peningkatan jumlah siswa yang mampu mengorganisasikan isi karangan dengan menggunakan pendekatan terpadu dengan baik pada akhir siklus.

\section{PEMBAHASAN DAN HASILPENELITIAN \\ Pembahasan}

Kondisi Awal Kemampuan Menulis Siswa Sebelum tindakan kelas dilaksanakan langkah yang ditempuh peneliti adalah mengetahui kondisi awal kemampuan menulis siswa. Data ini diperoleh dari hasil wawancara dengan guru bahasa Indonesia kelas V, bahwa data kondisi awal siswa didapat dari dokumen yang berupa nilai kemampuan menulis siswa (nilai ulangan/tugas) semester sebelumnya.

\section{Hasil Uji Coba Kemampuan Menulis Pelaksanaan Tindakan Kelas}

Pelaksanaan penelitian tindakan kelas ini meliputi beberapa siklus yang berdaur ulang dan berkelanjutan dari siklus pertamake siklus berikutnya. Setiap siklus meliputi kegiatan perencanaan tindakan (planning), implementasi tindakan (acting), observasi (observing), dan refleksi (reflecting). Setiap siklus dilakukan dengan memberikan tindakan pelatihan dan diakhiri dengan praktik menulis.

\section{a. Rencana Tindakan}

Pada tahap ini peneliti dan guru berkolaborasi untuk menyusun perencanaan pembelajaran atau scenario pembelajaran menulis dengan pendekatan terpadu. Rencana pembelajaran siklus I itu ditetapkan pendekatan terpadu yang pertama yaitu dengan memberikan pelatihan persepsi tentang keterpaduan pembelajaran menulis dengan bidang lain.

\section{b. Pelaksanaan Tindakan}

Siklus ini ada empat pertemuan, dari empat pertemuan tersebut yang digunakan untuk khusus untuk pembelajaran terpadu dalam keterampilan menulis dua pertemuan (masing-masing pertemuan 100 menit). Pola-pola pembelajaran kemampuan menulis dapat bervariasi, antara lain sebagai berikut.

Menyimak - berdiskusi - menulis

Berdiskusi - menulis - membaca

Menulis - melaporkan - membaca 
Membaca - menulis - berdiskusi.

\section{c. Observasi (Hasil Tindakan)}

Guru dibantu peneliti mencatat pada lembar pengamatan siapa saja yang berhasil dan siapa saja yang belum berhasil mengerjakan tugasnya dengan baik. Dikatakan berhasil apabila siswa telah mendapat nilai minimal 75, kurang dari 75 masih dikategorikan hasilnya belum memadai (belum baik). Berdasarkan hasil tugas yang dikerjakan siswa tersebut dapat diketahui bahwa setiap tugas yang dikerjakan hasilnya ada peningkatan yang signifikan dengan kemampuan menulisnya.

\section{Hasil Penguasaan Struktur}

Bahasa dalam Keterampilan Menulis Siswa Pada siklus ini seperti terlihat di tabel 2 tentang penguasaan struktur bahasa, siswa yang mendapat (1) nilai 0-40 adalah $0 \%$, (2) nilai 41-50 adalah 2,5\%, (3) nilai 51-60 adalah 27,5\%, (4) nilai antara 61-79 adalah57,5\%, dan (5) 80-100 adalah $12,5 \%$.

\section{Hasil Penelitian}

Kemampuan menulis merupakan sebuah kompetensi dasar dalam Kurikulum SD Kelas Tinggi dan sebuah tuntutan zaman. Oleh karena itu, kemampuan menulis perlu diajarkan sebaik mungkin. Di dalam pendekatan terpadu untuk kemampuan menulis, peneliti menggabungkan beberapa model pembelajaran keterampilan berbahasa ini. Dalam pembelajaran yang dilakukan ditekankan materi pembelajaran menulis dengan pengembangan topik dan pemberian tugas-tugas pada setiap materi tertentu. Realisasi pembelajaran kemampuan menulis secara terpadu terikat dua hal, yaitu (1) keseluruhan proses pembelajaran berorientasi pada kebermaknaan dan (2) pembelajaran berorientasi kepada pembelajar. Di dalam pembelajaran ini porsi menulis lebih banyak dibandingkan dengan aspek keterampilan yang lain. Pola-pola pembelajaran kemampuan menulis dapat bervariasi.

Realisasi pembelajaran kemampuan menulis secara terpadu terikat dua hal, yaitu (1) keseluruhan proses pembelajaran berorientasi pada kebermaknaan dan (2) pembelajaran berorientasi kepada pembelajar. Menerapkan pola pembelajaran dengan "Diskusi-menulis-membaca". Hasil tes menulis dengan menekankan penguasaan struktur bahasa dalam meningkatkan kemampuan menulis tersebut dapat diketahui bahwa siswa yang mendapat nilai antara 0-40 tidak ada seorang pun, sedangkan yang mendapat nilai antara 41-59 ada 1 orang, nilai antara 60-69 ada 14 orang, nilai antara 70-80 ada 16 orang, dan nilai antara 81-100 sebanyak 5 orang siswa. Nilai rata-rata siswa sebesar 65. Hasil yang dicapai siswa tersebut belum memenuhi tujuan yang diharapkan. Kenyataan menunjukkan bahwa pemberian bimbingan belajar dalam pengembangan menulis dan bombongan dari guru perlu diberikan agar siswa memiliki kepercayaan diri terhadap kemampuan yang dimiliki terhadap hasil menulisnya juga ikut membatu keberhasilan tulisannya. Pembelajaran berikutnya guru harus mampu mengaktifkan siswa agar kelas dapat lebih maju dan guru harus membantu siswa yang mengalami kesulitan dalam menulis. Pelatihan dalam siklus I ini ternyata siswa belum secara maksimal dapat meningkatkan kemampuan menulisnya. Hal ini tampak pada perolehan hasil menulisnya kaitannya dengan penguasaan struktur bahasa belum memadai atau masih sedang (23 orang atau 57,5\%). 
Dengan demikian, dalam meningkatkan kemampuan menulis pada siklus selanjutnya, penguasaan struktur bahasa masih perlu ditekankan atau diperhatikan lagi, khususnya pada bagian pembentukan kata, frasa, dan ungkapan baru yang masih minim. Guru menyampaikan indikator (tujuan pembelajaran). Indikator pembelajaran yang diharapkan adalah para siswa mampu melaksanakan pelatihan dengan baik tentang bagaimana penyusunan kalimat efektif dalam karangan/menulis hingga dapat mencapai target kemampuan menulis (KM) sebedar $75 \%$.

Adapun pola pembelajaran terpadu yang digunakan dalam pembelajaran keterampilan menulis ini adalah pola "menulis-melaporkan membaca". Terakhir siswa diberi tes keterampilan menulis. Dari hasil tes keterampilan menulis yang menekankan persyaratan kalimat efektif yang meliputi kebenaran struktur (correctness) dan kecocokan konteks (appropiacy) oleh siswa tersebut nilai terendah yang dicapai siswa adalah 54 dan nilai tertinggi 83, sedangkan nilai ratarata tes 65 . Hal ini tampak pada perolehan hasil menulisnya kaitannya dengan penyusunan kalimat efektif sudah baik ( 24 orang dari 40 siswa telah mencapai nilai tersebut 70 atau nilai rata-rata $72 \%$ ). Dengan demikian, dapat dikatakan bahwa berdasarkan hasil tes keterampilan menulis siswa tersebut sudah lebih baik dari hasil tes sebelumnya. Dengan perkataan lain bahwa kemampuan menulis dengen menekankan penguasaan struktur bahasa siswa setelah diadakan pelatihan ulang hasilnya meningkat lebih baik dibandingkan sebelumnya.

\section{KESIMPULAN DAN SARAN Kesimpulan}

Penggunaan (penerapan) pendekatan pembelajaran terpadu di dalam pembelajaran kemampuan menulis dalam pembelajaran bahasa Indonesia ternyata dapat meningkatkan kemampuan menulis siswa. Hal ini terindikasi dari adanya peningkatan perolehan kemampuan menulis $(\mathrm{KM})$ yang rendah meningkat ke KM yang lebih tinggi. Pelaksanaan pembelajaran bahasa Indonesia berjalan efektif dalam menerapkan pendekatan terpadu dapat mensinergikan antara kemampuan fisik dan kemampuan psikis sehingga kemampuan menulisnya meningkat. Peningkatan kemampuan menulis siswa SD kelas tinggi setelah diterapkan pendekatan terpadu dalam pembelajaran bahasa Indonesia adalah pada kondisi awal perolehan nilai $\mathrm{KM}$ adalah 57,5\%. Pada siklus perolehan $\mathrm{KM}$ tertinggi adalah $65 \%$.

\section{Saran}

Pertama, siswa disarankan agar terus menerus berlatih menulis agar dapat meningkatkan keterampilan menulisnya. Semakin banyak berlatih menulis, siswa akan semakin lancar dan mudah di dalam mengungkapkan atau menyampaikan buah pikiran, perasaan, pengalaman, dan pendapatnya dalam bentuk bahasa tulis kepada orang lain.Kedua, di dalam meningkatkan keterampilan menulis siswa, para guru hendaknya menunda terlebih dahulu tugas mengarang secara bebas untuk itu program menyusun karangan terarah perlu diberikan kepada siswa. Salah satu wujud komposisi terarah adalah pemberian latihan menganalisis aspekaspek kebahasaan dan teknik penulisan. Aspek-aspek karangan yang menjadi fokus bagi kegiatan menyusun karangan terarah itu dapat bersifat tunggal (misalnya, ejaan atau tanda baca atau pengorganisasian paragraf), tetapi dapat 
mencakup beberapa aspek karangan sekaligus. Hasil dari pemberian program latihan itu adalah makin meningkatnya kemampuan siswa dalam mengungkapkan gagasan. Ketiga, bagi pengajar ketrampilan berbahasa Indonesia di program SD Kelas Tinggi hendaklah mengajarkan materi keterampilan berbahasa (keterampilan berbicara, menyimak, membaca, dan menulis) diberikan dalam satu kesatuan (terpadu) karena pada keempat keterampilan tersebut tidak dapat dipisahkan satu dengan yang lain. Keempat, pengajar keterampilan berbahasa Indonesia di dalam membelajarkan keterampilan menulis lebih banyak menekankan pada aspek-aspek kebahasaan, mengingat selama ini sebagian pengajar lebih menekankan kepada faktor keindahan dan kebenaran bentuk tulisan dalam mengoreksi karangan siswa. Penilaian yang lebih menitikberatkan pada bentuk penulisan tidak sesuai dengan tujuan pembelajaran menulis yang hendak dicapai, yaitu agar siswa mampu berkomunikasi dengan bahasa tulis.

\section{DAFTAR PUSTAKA}

Keraf, G. 1984. Argumentasi dan Narasi. Jakarta: PT Gramedia.

Harris, P. 1974. Testing English as a Second Language. New York: Tata Mc Graw Hill.

Heaton, J.B. 1983. Writing English Language Texts. Singapore: Longman Gr.

Syafi'e, I. 1993. Terampil Berbahasa Indonesia I. Jakarta: Departemen Pendidikan dan Kebudayaan.

Sumardi, M (ed). 1992. Berbagai Pendekatan dalam Pengajaran Bahasa dan Sastra. Jakarta: Pustaka SinarHarapan.

Morgan, C. T. 1986. Introduction Psychology. New York: Mc Graw-Hill Book Copany.

Ngalimun. 2013. Bahasa Indonesia di Perguruan Tinggi. Yogyakarta: Aswaja Pressindo

Ngalimun. 2013. Pembelajaran Keterampilan Berbahasa Indonesia. Yogyakarta: Aswaja Pressindo

Ngalimun. 2014. Strategi dan Model Pembelajaran. Yogyakarta: Awsaja Pressindo

Ramlan. 1983. Penyusunan Tata Bahasa Struktural Bahasa Indonesia : Pedoman Penulisan Tata Bahasa. Jakarta: Departemen Pendidikan dan kebudayaan.

Akhadiah, S dkk. 1996. Pembinaan Kemampuan Menulis Bahasa Indonesia. Jakarta: Erlangga. 
Stilistika: Jurnal Bahasa, Sastra, dan Pengajarannya ISSN 2527-4104

Vol. 2 No.1, 1 April 2017

Savignon, S. J. 1983. Communicative Competence: Theory and Classroom Practise. New York: Addison Wesley Publishing Company Inc.

Tampubolon. 1990. Kemampuan Membaca, Teknik Membaca Efektif dan Efisien. Bandung: Angkasa. 